"Synthesis and structural properties of oligonucleotides covalently linked to acridine and quindoline derivatives through a threoninol linker" Aviñó, A., Mazzini, S., Ferreira, R., Eritja, R. Bioorg. Med. Chem., 18(21), 7348-7356 (2010). doi: 10.1016/j.bmc.2010.09.023

\title{
Synthesis and structural properties of oligonucleotides covalently linked to acridine and quindoline derivatives through a threoninol linker
}

\author{
Anna Aviño, ${ }^{a}$ Stefania Mazzinib ${ }^{\text {,* }}$ Rubén Ferreira, ${ }^{a}$ and Ramon Eritja, ${ }^{a}{ }^{*}$ \\ ${ }^{a}$ Institute for Research in Biomedicine (IRB Barcelona), Networking Centre on Bioengineering, \\ Biomaterials and Nanomedicine (CIBER-BBN) and Institute for Advanced Chemistry of Catalonia \\ (IQAC), CSIC, Baldiri Reixac 10, E-08028 Barcelona. Spain, (Email: aaagma@cid.csic.es; \\ ruben.ferreira@irbbarcelona.org, recgma@cid.csic.es). ${ }^{b}$ Dipartimento di Scienze Molecolari \\ Agroalimentari, Università degli Studi di Milano, via Celoria 2, 20133 Milano, Italy, (Email: \\ stefania.mazzini@unimi.it ).
}

Corresponding author:

Ramon Eritja

IRB Barcelona

IQAC-CSIC

CIBER-BBN

Baldiri Reixac 10

E-08034 Barcelona, Spain

Email: recgma@cid.csic.es

Phone $+34-934039942$

Fax +34-932045904

Keywords: oligonucleotide synthesis, DNA duplex, DNA-binding drugs, DNA, intercalating agents, acridine, quindoline, threoninol, quadruplex, thrombin binding aptamer, NMR. 


\begin{abstract}
Oligonucleotide conjugates containing acridine and quindoline derivatives linked through a threoninol molecule were synthesized. We showed that these conjugates formed duplexes and quadruplexes with higher thermal stability than the corresponding unmodified oligonucleotides. When acridine is located in the middle of the sequence, DNA duplexes have a similar stability independently of the natural base present in front of acridine. Self-complementary oligonucleotides and thrombin binding aptamers (TBA) carrying the acridine and quindoline molecules are studied by NMR.
\end{abstract}

\title{
1. Introduction
}

There is a current interest in conjugation of oligonucleotides with DNA-binding drugs that provides an addition binding energy without perturbing the specific recognition with the complementary sequences. It has been shown that oligonucleotide conjugates with intercalating molecules may be accomplished by linking oligonucleotides via linker arms to intercalating agents at the 3' or 5' terminal positions, in the nucleobases or in the internucleotide backbone [1].

Oligonucleotide conjugates carrying DNA-binding drugs have been applied to different purposes. For example they have been used to specifically inhibit the expression of a gene through binding with mRNA (the antisense approach) or DNA (the antigene approach). Oligonucleotides carrying DNA-binding drugs have demonstrated to stabilized the duplex structure, improve nuclease resistance and improve cellular uptake $[1,2]$ so that they may be considered good candidates for therapeutic uses. It is quite common to link intercalating agents to one or both ends of an oligonucleotide to form triplex forming oligonucleotides with higher binding affinity [3]. Acridine derivatives have also been introduced in peptide nucleic acids (PNA) yielding PNA derivatives with enhanced cellular uptake properties [4]. Finally, oligonucleotide primers functionalized with minor groove binding molecules are being used in PCR reactions [5].

Besides interaction with double strand DNA, intercalating agents may also interact with Gquadruplex [6]. This secondary structure formed by four nucleic acids strands in which guanine bases forms stacked planar tetrads stabilized by hydrogen bonds. Sequences with a high propensity to form quadruplexes are more likely to be found in gene promoters, protooncogenes or telomeres. Quadruplex binding ligands have medicinal interest because they can regulate gene expression. Intercalating units conjugated to oligonucleotides are also used to stabilize quadruplex structures [7] providing a stacking interaction between guanine tetrads and the aromatic moieties of the intercalating molecule. 
Several strategies for the incorporation of intercalating agents in oligonucleotides have been described. This includes: 1) Incorporation of reactive groups (such as terminal phosphate, thiophosphate, amino, carboxylic or diol groups) into oligonucleotides and subsequent coupling with intercalating agents carrying the appropriate reactive groups, and 2) Use of a derivative of the intercalating agent compatible with oligonucleotide synthesis conditions. Recently we have described a method for the preparation of oligomeric molecules by linking several DNA-binding

drugs $[8,9]$. To this end, the preparation of several types of DNA-intercalating units having functional units as well as specific protecting groups for the stepwise assembly of several DNAintercalating units using solid-phase synthesis protocols was described $[8,9]$. Of special interest are the threoninol derivatives of acridine and quindoline (Act and Qut, figure 1A) because they are fluorescent, they have affinity to duplex DNA and they are compatible with oligonucleotide synthesis conditions [8]. For these reasons they are ideal for the rapid preparation of oligonucleotides carrying one or several DNA-intercalating units (Figure 1B).

Figure 1

In this paper we present the synthesis and the structural properties of oligonucleotides linked to one or several acridine and/or quindoline molecules using the threoninol backbone [10]. The presence of the DNA-intercalating unit at the 3'-end of the oligonucleotides induce a strong stabilization of duplex and quadruplex structures. When acridine is located in the middle of the sequence, duplexes have a similar stability independently of the natural base present in front of acridine. NMR data indicate that quindoline derivatives show a selective interaction for A-T base pairs in duplex DNA, whereas interactions with the TGT loop of the quadruplex structure of the thrombin-binding aptamer (TBA) are observed. A model of the structure of TBA conjugated to quindoline is reported. These results demonstrate that linking DNA-binding drugs to oligonucleotide may produce new DNA derivatives with tailored structural properties.

\section{Results and discussion}

\subsection{Oligonucleotide synthesis.}

L-threoninol was selected to conjugate molecules to DNA. Threoninol has been used to introduce several units of Methyl Red moieties [10], photoactive azobenzenes [11, 12], acridine [13], pyrene 
and perylene [14], tetrathiofulvalene [15] and DNA-binding drugs [8, 9] in oligonucleotides. This compound can be obtained enantiomerically pure from commercial sources and have two hydroxyl groups (one primary and one secondary) and one amino group. The amino group position can be used for attaching the DNA-intercalating drug. Then, the primary hydroxyl group can be protected with the 4,4'-dimethoxytrityl (DMT) group. Finally the secondary alcohol was used to prepare the phosphoramidite or the hemisuccinate derivatives needed for the assembly of oligomers using solidphase methods [8].

These compounds were used for the preparation of solid supports carrying monomers (Act and Qut) and the corresponding dimers (Act-p-Act, Act-p-Qut, Qut-p-Act and Qut-p-Qut, Figure 1). The solid supports functionalized with monomers and dimers were used to prepare a series of DNA sequences including two self-complementary octamers (OCT1: 5'-TTCCGGAA-3' and OCT2: 5'CCAATTGG-3'), the thrombin binding aptamer [16] (TBA: 5'-GGTTGGTGTGGTTGG-3') and the two DNA sequences containing an acridine molecule in the middle of the sequence (9mer: TTCC-Act-p-GGAA and 15mer: 5'-GCAATGGA-Act-p-CCTCTA-3'). Moreover, two octamers and one TBA derivative carrying a tetraethyleneglycol $(\mathrm{EG})_{4}$ spacer between the oligonucleotide and the quindoline derivative were prepared to allow more conformational freedom to the DNAbinding molecule in order to find the optimal position for DNA-binding. The assembly of the oligonucleotides was performed on a DNA synthesizer and oligonucleotides were assembled using standard protocols. After the assembly of the desired DNA sequence, supports were treated with concentrated ammonia at $55^{\circ} \mathrm{C}$ yielding oligonucleotides carrying DNA-binding molecules either at the 3'-end or at internal positions (see Table 1 and Table 2). In all cases a major peak was obtained that was isolated and characterized by mass spectrometry (Table 1).

\subsection{Thermal denaturation studies.}

The effect of the presence of the oligomeric intercalators on DNA duplex stability was measured by melting experiments. Results are shown in Table 1. In general the presence of the intercalating drug on the $3^{\prime}$-end of the oligonucleotide increases the melting temperature up to $14.7^{\circ} \mathrm{C}\left(7.3{ }^{\circ} \mathrm{C}\right.$ per modification) of the duplex indicating an interaction of the drug with the duplex structure of DNA. The increase on melting temperatures was higher on OCT1 $\left(\Delta \mathrm{Tm} 8.9-14.7^{\circ} \mathrm{C}\right)$ than on OCT2 $(\Delta \mathrm{Tm}$ 1.1-11.7 ${ }^{\circ} \mathrm{C}$ ). In most of the cases the presence of two intercalating (acridine or quindoline) molecules led to a slight increase on melting temperatures. The highest melting temperatures were observed for the octamers carrying a quindoline molecule tethered with a tetraethyleneglycol molecule. When acridine was incorporated in the middle of a self-complementary sequence, the 
resulting duplex with an acridine-acridine pair had a lower melting temperature $\left(\Delta \mathrm{Tm}-3{ }^{\circ} \mathrm{C}\right)$ than the unmodified octamer 1 duplex (Table 1).

Melting temperatures of duplexes containing an acridine in the middle of the sequence paired with the four natural bases are shown in Table 2. The most stable duplex is the duplex that contains an acridine in front of thymine $\left(53.9^{\circ} \mathrm{C}\right)$. This melting temperature is similar $\left(\Delta \mathrm{Tm} 0.6{ }^{\circ} \mathrm{C}\right)$ than the Tm of a duplex carrying an A-T base pair $\left(53.3^{\circ} \mathrm{C}\right)$ but lower than the duplex carrying a G-C base pair $\left(54.7^{\circ} \mathrm{C}\right)$. It is important to mention than the melting temperatures of the duplexes of acridine paired with all the four natural bases have very small differences between them (Tm 51.3-53.9). This tendency to similar melting temperatures may be beneficial in the design of degenerate primers or probes. The spread on melting temperatures when acridine is paired with natural bases $\left(2.6^{\circ} \mathrm{C}\right)$ compared well with $\mathrm{Tm}$ data reported for other candidates for universal bases $\left(3^{\circ} \mathrm{C}\right.$ for nitropyrrole [17], 5-nitroindole [18] and 8-aminohypoxanthine [19]; $2^{\circ} \mathrm{C}$ for acyclic 5-nitroindazole [20] and 8aza-7-deaza-dA [21]). The stabilizing effect of acridine is in agreement with previous results obtained with insertion of 1-O-(1-pyrenemethyl)glycerol in dsDNA [22].

Melting curves of thrombin binding aptamers carrying acridine and quindoline derivatives were performed by UV spectroscopy and compared with the unmodified sequences. The results, summarized in Table 1, indicate that all TBA aptamers considered show a weak stabilization of the quadruplex structure $\left(\Delta \mathrm{T}_{\mathrm{m}} 3.5^{\circ} \mathrm{C}-7.5^{\circ} \mathrm{C}\right)$. Moreover, the $\mathrm{CD}$ spectra of native TBA and of TBAcomplexes are characterized by a positive band at $248 \mathrm{~nm}$, a negative maximum at $265 \mathrm{~nm}$ together with a positive maximum at $295 \mathrm{~nm}$ typical of an antiparallel quadruplex structure (see supplementary data, figure $1 \mathrm{~S})$.

\subsection{NMR studies on TBA derivatives.}

The observation of the imino proton region of NMR spectra at $5^{\circ} \mathrm{C}$ of selected modified TBA sequences (TBA-p-Act, TBA-p-Qut, and TBA-(EG) $\left.)_{4}-p-Q u t\right)$ confirm the formation of a quadruplex structure, however spectrum changes compared to the unmodified aptamer are observed (Fig. 2). TBA-p-Act and TBA-(EG) 4 -p-Qut show sharp and disperse signals, according with the presence of a unique G quadruplex structure whereas TBA-p-Qut presents broad signals characteristic of solution conformational equilibria.

Figure 2 
The examination of the imino proton region of TBA-(EG) 4 -p-Qut as a function of temperature showed that the signals disappear around $55^{\circ}-65^{\circ} \mathrm{C}$ (the melting temperature of the unmodified TBA is about $46^{\circ} \mathrm{C}$ ) confirming the thermal stabilization (Fig. 3).

Figure 3

A set of $2 \mathrm{D}$ NMR spectra, performed at $5^{\circ} \mathrm{C}$ of TBA aptamers, were analyzed. Specifically, we identified, in the aromatic region of TBA-(EG) 4 -p-Qut, 15 signals belonging to nine $\mathrm{H} 8$ of $\mathrm{G}$ and six thymine H6 protons. The pattern of NOEs observed indicates that the global backbone conformation is similar to that of the native aptamer. The strong intensities of intraresidue NOE cross peaks between $\mathrm{H} 8$ of $\mathrm{G}$ and $\mathrm{H} 1$ ' confirm the syn glycosidic conformation for G1, G5, G10 and G14. We detected NOE connectivities between non adjacent residues such as H8G2 and H8G11 with the methyl and H2' and H2' of T4 and T13 respectively, and interactions between H8G8 and H2', H2' and H1' of G6 and between H8G15 with H1'T9. The chemical shift of exchangeable and non exchangeable protons of the unmodified aptamer was compared with those of the TBA-(EG) 4 -p-Qut. Only little differences $\Delta \delta<0.1 \mathrm{ppm}$ were observed, except for the H8G6 ( $\Delta \delta=0.12 \mathrm{ppm}$ downfield), H6 of T7 and T9 $(\Delta \delta=0.15 \mathrm{ppm}$ and 0.21 upfield, respectively), H8G14 and G15 ( $\Delta \delta=0.12$ and 0.11 ppm upfield, respectively).

Quindoline resonances were also assigned: H9 proton was assigned by a strong NOE cross peak with the indolic $\mathrm{NH}$ which shows a typical chemical shift (10.55 ppm). This led to the assignment of its vicinal proton $\mathrm{H} 8$ and then $\mathrm{H} 7$ and H6. Moreover, the $\mathrm{NH}$ amidic proton (8.90 ppm) showed a strong and a medium NOE cross peak with two aromatic protons, allowing the assignment $\mathrm{H} 1$ and $\mathrm{H} 2$ respectively (Fig. 4). This scheme of intramolecular NOE interactions for quindoline moiety shows that the peptidic bond is in trans conformation further confirmed by NOEs interactions between indolic $\mathrm{NH}$ and $\mathrm{H} \alpha, \mathrm{H} \beta$ and Me. The chemical shifts of all resonances of TBA-(EG) $)_{4}$ - Qut are reported in Table 3.

Figure 4

The NOE experiments, allowing the detection of specific interactions between protons of the ligand and protons of the DNA, were analyzed in order to recognize possible preferred interaction sites. In particular, two well separated resonances at $1.28 \mathrm{ppm}$ and at $1.43 \mathrm{ppm}$ were attributed to the methyl $\beta$ of quindoline moiety. Each methyl group shows interactions NOE with TBA, attributed to T9, G8 and G6 residues, respectively i.e one set of interactions involves T9 and G8 located in the lateral 
loop, whereas the second one, characterized by a lower number of NOEs, involve G6 residue (Table 4) (Fig. 5A)

Figure 5

We conclude that there are in solution two modes of binding, differing for the position of the quindoline moiety. There were no interactions between the Qut moiety and the G quadruplex tetrads but with the TGT loop (Fig. 6).

The same experiments were performed on TBA-p-Qut and TBA-p-Act complexes which show a quadruplex architecture with a $\mathrm{T}_{\mathrm{m}}=50.7^{\circ} \mathrm{C}$ and $\mathrm{T}_{\mathrm{m}}=49.7^{\circ} \mathrm{C}$ respectively. TBA-p-Qut $2 \mathrm{D}$ spectra are characterized by broad signal indicating that the scheme of chemical equilibria present in solution should be much more complicated than that one depicted for TBA-(EG) ${ }_{4}$-p-Qut (Fig. 5B).

On the contrary, the general appearance of the NOESY spectra of TBA-p-Act was better compared to that of the TBA-p-Qut (Fig. 5C). The signals are sharper and well resolved thus allowing an almost complete assignment (see Table 1 in Supplementary Material). In this case only few contacts points were detected at the level of G15 and G11 (H1, H2, and H6 of Act with H2' and H2" of G15, $\mathrm{H} \alpha$ with H8G11) indicating that the acridine moiety is located near the G quartet plane.

Figure 6

\subsection{NMR studies on self-complementary octamers.}

The $\mathrm{T}_{\mathrm{m}}$ data reported in Table 1 relatively to octamers indicate that the presence of the ligand induces a stabilization of the double helix. On this basis some octamer adducts were selected for NMR studies.

The extensive overlapping of quindoline aromatic protons of OCT1-p-Qut adduct made the analysis quite difficult (see Table 2 in Supplementary Material), nevertheless few NOEs interactions (H2 A8, H1' $\mathrm{T} 1$ and/or $\mathrm{T} 2$ and $\mathrm{H} 2$ ' $\mathrm{T} 2$ with quindoline aromatics protons) indicate the interaction with the AT base pairs. These findings were confirmed by an up field shift ( $\Delta \delta 0.2-0.3 \mathrm{ppm})$ of aromatic protons of the oligonucleotide at the level of A8T1 units in comparison with the unmodified octamer. The same type of interactions were found for OCT1-(EG) 4 -pQut, containing tetraethylene glycol as a spacer between DNA and ligand. For both complexes the chromophore moiety is located and interacts at the A8T1 terminal 3' end of the double helix suggesting the formation of a CAPcomplex by stacking the aromatic rings with the adenine and thymine units. A generalized line broadening of the NMR spectra suggest the presence of multiple equilibria in this case. Chemical 
shift assignments for OCT1-(EG) 4 -pQut at $10^{\circ} \mathrm{C}$ and $25^{\circ} \mathrm{C}$ are reported in Table 5 and Table $3 \mathrm{~S}$ respectively.

In addition, we also studied the OCT2-(EG) 4 -p-Qut, where the AT base pairs are in the middle of the sequence. Contacts of the quindoline aromatic protons and $\mathrm{H} \beta$ of the threoninol with $\mathrm{H} 6 \mathrm{~T} 5$, Me T5, Me T6, H1'T5 and with H1' A4 were found confirming an intercalation at the level of A4T5 base pairs as preferred binding site. Moreover some intramolecular NOEs cross peaks (H6T5/H1'A4, H8A4/H3'A4 and H8A4/H3'A3) resulted weaker in comparison with the same in the unmodified OCT2. The signals of H8, H1', H2', H2" of A4 and Me of T5 are found split (Table 6). The observed split could be attributed to the loss of the symmetry of the double helix due to a non symmetric interaction of the quindoline moiety. This result agrees with the data reported in Table 1 , where $\Delta \mathrm{Tm}$ is only $1.1^{\circ} \mathrm{C}$ for OCT2-p-Qut increasing to $11.7^{\circ} \mathrm{C}$ when the spacer was inserted, allowing the interaction with the internal AT base pairs.

\section{Conclusions}

In conclusion we have shown that oligonucleotides carrying one or two acridine and quindoline derivatives linked through a threoninol molecule can be synthesized with high efficiency using solid-phase protocols. DNA duplexes and quadruplexes carrying acridine and quindoline derivatives have higher thermal stability compared with the corresponding unmodified oligonucleotides. When acridine is located in the middle of the sequence, duplexes have a similar stability independently of the natural base present in front of acridine. NMR studies show that the quindoline moiety is capable to interact onto the A-T base pair of DNA duplexes. Moreover the quindoline moiety of TBA-(EG) 4 -p-Qut interacts with the TGT loop of the aptamer. These results reveal that DNA-binding molecules linked to different structures could be used for the stabilization of these structures and this information may be used in the design of oligonucleotide-based drugs with improved biological properties. Moreover the hydrophobicity and fluorescent properties of the acridine and quindoline derivative may found utility of the design of new oligonucleotide derivatives with better cellular uptake properties. Work in these directions is currently being done and results will be presented in due course.

\section{Experimental section}

5.1. Materials. All the standard phosphoroamidites and reagents for DNA synthesis were purchased from Applied Biosystems and from Link Technologies. L-threoninol, tetraethylene glycol, acridine- 
9-carboxylic acid and the rest of chemicals were purchased from Sigma-Aldrich and Fluka. $10 \mathrm{H}$ Indolo[3,2b]quinoline-11-carboxylic acid and the threoninol derivatives of acridine and quindoline were prepared as described [8]. The $O$-2-cyanoethyl- $N, N$-diisopropyl phosphoramidite of tetraethyleneglycol was prepared as described [23].

5.2. Oligonucleotide synthesis and purification: The synthesis of the oligonucleotides was performed at $1 \mu \mathrm{mol}$ scale on an Applied Biosystems DNA/RNA 3400 synthesizer by solid-phase 2-cyanoethylphosphoroamidite chemistry. The following sequences were prepared: OCT1: d(5'TTCCGGAA-3'), OCT1-p-Qut: d(5'-TTCCGGAA-3'-p-Qut), OCT1-p-Qut-p-Qut: $\quad$ d(5'TTCCGGAA-3'-p-Qut-p-Qut), OCT1-p-Act: d(5'-TTCCGGAA-3'-p-Act), OCT1-p-Act-p-Act: d(5'-TTCCGGAA-3'-p-Act-p-Act), OCT1-p-Act-p-Qut: d(5'-TTCCGGAA-3'-p-Act-p-Qut), OCT1-(EG) - $_{4}$-Qut: d(5'-TTCCGGAA-3'-(EG) - $_{4}$-p-Qut), d(5'-TTCC-Act-p-GGAA-3'), OCT2: d(5'-CCAATTGG-3'), OCT2-p-Qut: d(5'-CCAATTGG-3'-p-Qut), OCT2-p-Qut-p-Qut: d(5' CCAATTGG-3'-p-Qut-p-Qut), OCT2- p-Act-p-Qut: d(5'-CCAATTGG-3'-p-Act-p-Qut), OCT2-pAct: d(5'-CCAATTGG-3'-p-Act), OCT2-(EG) 4 -p-Qut: d(5'-CCAATTGG-3'-(EG) ${ }_{4}$-p-Qut), TBA: d(5'-GGT TGG TGT GGT TGG-3'); TBA-p-Act: d(5'-GGT TGG TGT GGT TGG-3'-p-Act), TBA-p-Qut: d(5'-GGT TGG TGT GGT TGG-3'-p-Qut), TBA-p-Qut-p-Act: d(5'-GGT TGG TGT GGT TGG-3'-p-Qut-p-Act), TBA- p-Act-p-Qut: d(5'-GGT TGG TGT GGT TGG-3'-p-Act-p-Qut), TBA-p-Act-p-Act: d(5'-GGT TGG TGT GGT TGG-3'-p-Act-p-Act), TBA-(EG) 4- p-Qut: d(5'GGT TGG TGT GGT TGG-3'-(EG) 4 -p-Qut), 15mer: d(5'-GCA ATG GA-Act-p-CCT CTA-3').

The threoninol derivatives (Act and Qut) were prepared as previously described [8]. The DMT derivatives were coupled to CPG supports by the succinyl linker or reacted with $O$-2-cyanoethyl$\mathrm{N}, \mathrm{N}$-diisopropyl-chlorophosphine to yield the corresponding phoshoramidite [8]. The resulting CPG solid supports functionalized with Act and Qut [8] were incorporated directly in the DNA synthesizer to perform the synthesis of the corresponding oligonucleotide sequences. The same strategy was used to prepare oligomers carrying two chromophore units (-p-Act-p-Act, p-Qut-pQut, -p-Act-p-Qut and -p-Qut-p-Act) linked by phosphorodiester backbone [8]. The resulting solid supports containing the dimers were used as start point for the synthesis of the oligodeoxynucleotides. Step-coupling yields of the threoninol phosphoramidites were similar to standard phosphoroamidites. After the assembly of the desired sequences, ammonia treatment was performed at $55^{\circ} \mathrm{C}$ for $6 \mathrm{~h}$. Oligodeoxynucleotides were purified using a reversed-phase HPLC (DMT off method). Solvent A: $5 \% \mathrm{MeCN}$ in $100 \mathrm{mM}$ triethylammonium acetate (pH 6.5) and solvent B: $70 \% \mathrm{MeCN}$ in $100 \mathrm{mM}$ triethylammonium acetate (pH 6.5). Column: Nucleosil120C18 
$(10 \mu \mathrm{m}, 200 \times 10 \mathrm{~mm})$. Flow rate: $3 \mathrm{ml} / \mathrm{min}$. Conditions A: 20 min linear gradient from 0-50\% B. In all cases a major peak was obtained that was isolated and characterized by mass spectrometry. The resulting oligonucleotides were desalted in a Sephadex (NAP-10) G25 column. Oligonucleotides used for NMR studies were prepared on 1-2 micromol scale (OCT1, OCT1-p-Qut, OCT1-(EG) 4 -p-Qut, OCT2, OCT2-(EG) ${ }_{4}$-p-Qut, TBA, TBA-p-Act,TBA-p-Qut, TBA-(EG) 4 -p-Qut) were passed through a DOWEX $\left(\mathrm{Na}^{+}\right)$resin to exchange triethylammonium to sodium cations. Yields: OCT1-p-Qut: 59 OD units, OCT1-(EG) 4 -p-Qut: 78 OD units, OCT2-(EG) $)_{4}$-p-Qut: 73 OD units, TBA-p-Act: 86 OD units, TBA-p-Qut: 64 OD units, TBA-(EG) 4 -p-Qut: 70 OD units. The rest of the oligonucleotides were prepared on $200 \mathrm{nmol}$ scale obtaining around 10-20 OD units.

Oligonucleotides were characterized by mass spectrometry. MS (MALDI-TOF): see Table 1; 15mer: d(5'-GCA ATG GA-Act-p-CCT CTA-3'): found: 4624.5; expected 4621.7.

\subsection{Thermal denaturation experiments of oligonucleotides using UV spectroscopy.}

The thermal melting curves were performed following the absorption change at $295 \mathrm{~nm}$ for TBA aptamers and at $260 \mathrm{~nm}$ for octamers from a temperature of $20^{\circ} \mathrm{C}$ till $80^{\circ} \mathrm{C}$, with a linear temperature ramp of $0.5 \% \mathrm{~min}$ on a JASCO V-650 spectrophotometer equipped with a Peltier temperature control. All the measurements were repeated three times, conducted in $10 \mathrm{mM}$ sodium cacodylate buffer, $100 \mathrm{mM} \mathrm{NaCl}$ and $10 \mathrm{mM} \mathrm{KCl}(\mathrm{pH}$ 7.0) for TBA derivatives; in $100 \mathrm{mM}$ sodium phosphate buffer and $1 \mathrm{M} \mathrm{NaCl}(\mathrm{pH}$ 7.0) for the octamers and in $10 \mathrm{mM}$ sodium phosphate buffer and $50 \mathrm{mM} \mathrm{NaCl}(\mathrm{pH} 7.0)$ for the pentadecamers. The concentration of the samples were around 4$6 \mu \mathrm{M}$.

\subsection{Thermal denaturation experiments of oligonucleotides using circular dichroism.}

CD spectra for TBA and TBA-(EG) $)_{4}$-p-Qut were obtained following the change of ellipticity from $220 \mathrm{~nm}$ to $320 \mathrm{~nm}$ at different temperatures on a Jasco spectropolarimeter equipped with a Peltier temperature control used to set the temperature between $5^{\circ} \mathrm{C}$ and $75^{\circ} \mathrm{C}$. The changes in ellipticity versus temperatures at $\lambda_{\max }$ were plotted and used to obtain the melting temperature. All measurements were conducted in $10 \mathrm{mM}$ potassium phosphate buffer and $5 \mathrm{mM} \mathrm{KCl}$ (pH 6.9) for the aptamers. The concentration of the samples was $80 \mu \mathrm{M}$.

5.5. NMR Spectroscopy: The samples for NMR measurements were dissolved in $500 \mu 1 \mathrm{H}_{2} \mathrm{O} / \mathrm{D}_{2} \mathrm{O}$ (9:1) or $\mathrm{D}_{2} \mathrm{O}$ containing $10 \mathrm{mM}$ potassium phosphate buffer and $\mathrm{NaCl} 100 \mathrm{mM}$ (pH 6.7) or $5 \mathrm{mM}$ $\mathrm{KCl}$ ( $\mathrm{pH}$ 6.9) for octamers and TBA aptamers, respectively. The final concentrations of the oligonuclotides were $0.8 \mathrm{mM}-1.2 \mathrm{mM} .{ }^{1} \mathrm{H}$ NMR spectra were performed at temperatures ranging 
between $5^{\circ} \mathrm{C}$ and $65^{\circ} \mathrm{C}$ on a Bruker AV-600 spectrometer, equipped with a $z$-gradient triple resonance TXI and processed with TOPSPIN v. 1.3. 1D and 2D spectra were recorded, in the case of $\mathrm{D}_{2} \mathrm{O}$ solutions, with water suppression obtained by presaturation pulse sequences, while, in the case of $\mathrm{H}_{2} \mathrm{O} / \mathrm{D}_{2} \mathrm{O}$ solutions using a gradient-based solvent suppression.

Chemical shifts $(\delta)$ were measured in $\mathrm{ppm} .{ }^{1} \mathrm{H}$ spectra were referenced respectively to external DSS (2,2-dimethyl-2-silapentane-5-sulfonate sodium salt) set at $0.00 \mathrm{ppm}$.

Standard homonuclear 2D-NMR experiments were performed to assign the resonances of the complexes, including DQF-COSY, TOCSY and NOESY [24]. The mixing times were set at 150ms and 300ms for NOESY and $60 \mathrm{~ms}$ for TOCSY. Typically, 2048 x 1024 data points were acquired using TPPI [25] and transformed to a final $4 \mathrm{~K} \times 4 \mathrm{~K}$ real data matrix after apodisation with a $90^{\circ}$ and $90^{\circ}$-shifted sine-bell squared function in f2- and f1-domain, respectively. Baseline correction was achieved by a 5th-degree polynomial function. The program Sparky [26] was used to assign the NOESY cross-peaks. The unmodified TBA was previously assigned [27-29].

5.6. Molecular Modelling: Molecular models of the complexes were built with Insight II \& Discover (version 97.0 MSI, San Diego, CA) on a Silicon Graphics O2 workstation, using standard fragments from the Silicon Graphics library for the octamers and the drugs and starting from the solution structure for thrombin binding aptamer [29]. The AMBER [30] as force-field was utilized without explicit inclusion of solvent molecules, setting a distance-dependent relative permittivity $\varepsilon$ $=4.0 \mathrm{r}$ and scaling the 1-4 non bond interactions by a factor of 0.5 . For drugs, the potentials were set by similarity with the DNA aromatic and sugar atoms. The models were energy minimized with a steepest-descendent followed by conjugate gradient algorithm. The drug-DNA complexes were then constructed following the NOE interactions. Restraints were defined as quadratic well potentials with upper and lower limits on the basis of the above reported classes of NOE intensities with a force constant of $50 \mathrm{Kcal} \mathrm{mol}^{-1} \AA^{-2}$. The models were energy minimized and then a $100 \mathrm{ps}$ of restrained MD simulation was performed at a constant temperature of $300 \mathrm{~K}$. The average structure was subjected to a further minimization and taken as the starting structure for a subsequent $100 \mathrm{ps}$ MD simulation at $300 \mathrm{~K}$, sampling the trajectory every picosecond.

\section{Acknowledgments}

This study was supported by the "Dirección General de Investigación Científica y Técnica" (grant BFU2007-63287 and CTQ2010-20541), the COST project (G4-net, MP0802), the Program of the University of Milan for the Research (PUR 2009) and the Generalitat de Catalunya (2009/SGR/208). CIBER-BBN is an initiative funded by the VI National R\&D\&i Plan 2008-2011, 
Iniciativa Ingenio 2010, Consolider Program, CIBER Actions and financed by the Instituto de Salud Carlos III with assistance from the European Regional Development Fund. S. Mazzini received a short-term scientific mission grant from COST.

\section{References:}

1. Asseline, U.; Thuong, N. T.; Helene, C. New J. Chem. 1997, 21, 5.

2. Christensen, U. B.; Pedersen, E. B. Nucleic Acids Res. 2002, 30, 4918.

3. Brunet, E.; Corgnali, M.; Perrouault, L.; Roig, V.; Asseline, U.; Sorensen, M. D.; Babu, R. B.; Wengel, J.; Giovannangeli, C. Nucleic Acids Res. 2005, 33, 4223.

4. Shiraishi T., Nielsen, P. E. Nucleic Acids Res. 2004, 32, 4893.

5. Afonina, I.; Zivarts, M.; Kutyavin, I.; Lukhtanov, E.; Gamper, H.; Meyer, R. B. Nucleic Acids Res. 1997, 25, 2657.

6. Neidle, S. Curr. Opin. Struct. Biol. 2009, 19, 239.

7. Casals, J.; Debéthune, L.; Alvarez, K.; Risitano, A.; Fox, K. R.; Grandas, A.; Pedroso, E. Bioconjugate Chem. 2006, 17, 1351.

8. Aviñó, A.; Navarro, I.; Farrera-Sinfreu, J.; Royo, M.; Aymamí, J.; Delgado, A.; Llebaria, A.; Albericio, F.; Eritja R. Biorg. Med. Chem. Lett. 2008, 18, 2306.

9. Farrera-Sinfreu, J.; Aviñó, A.; Navarro, I.; Aymamí, J.; Beteta, N. G.; Varón, S.; Pérez-Tomás, R.; Castillo-Avila, W.; Eritja, R.; Albericio, F.; Royo, M. Bioorg. Med. Chem. Lett. 2008, 18, 2440.

10. Asanuma, H.; Shirasuka, K.; Takarada, T.; Kashida, H.; Komiyama, M. J. Am. Chem. Soc. 2003, 125, 2217.

11. Asanuma, H.; Takarada, T.; Yoshida, T.; Tamaru, D.; Liang, X.; Komiyama, M. Angew. Chem. Int. Ed. 2001, 40, 2671.

12. Kashida, H.; Liang, X., Asanuma, H. Curr. Org. Chem., 2009, 13, 1065.

13. Fukui, K.; Tanaka, K. Nucleic Acids Res. 1996, 24, 3962. 
14. Kashida, H.; Takatsu, T.; Segiguchi, K.; Asanuma, H. Chem. Eur. J. 2010, 16, 2479.

15. Schnippering, M.; Zahn, A.; Liu, S. X, Leumann, C.; Decurtins, S.; Fermin, D. J. Chem. Comm. 2009, 5552-5554.

16. Bock, L. C.; Griffin, L. C.; Latham, J. A.; Vermaas, E. H.; Toole, J. J. Nature 1992, 355, 564.

17. Nichols, R.; Andrews, P. C.; Zhang, P.; Bergstrom, D. E. Nature 1994, 369, 492.

18. Loakes, D.; Brown, D. M. Nucleic Acids Res. 1994, 22, 4039.

19. Cubero, E.; Güimil-García, R.; Luque, F. J.; Eritja, R. Orozco, M. Nucleic Acids Res. 2001, 29, 2522.

20. Van Aerschot, A.; Rozenski, J.; Loakes, D.; Pillet, N.; Schepers, G.; Herdewijn, P. Nucleic Acids Res. 1995, 23, 4363.

21. Seela, F.; Debelak, H. Nucleic Acids Res. 2000, 28, 3224.

22. Christensen, U. B.; Pedersen, E. B. Nucleic Acids Res. 2002, 30, 4918.

23. Rumney IV, S.; Kool, E. T. J. Am. Chem. Soc. 1995, 117, 5635.

24. Wutrich, K. NMR of proteins and nucleic acids; Wiley-Interscience: Weinheim, 1986. John Wiley \& Sons.

25. Redfield, A. G.; Kunz, S. D. J. Magn. Reson. 1975, 19, 250.

26. Goddard, T. D.; Kneller, D. G. (2004) SPARKY 3, University of California, San Francisco (USA).

27. Wang, K. Y.; McCurdy, S.; Shea, R. G.; Swaminathan, S., Bolton, P. H. Biochemistry 1993, 32, 1899.

28. Macaya, R. F.; Schultze, P.; Smith, F. W.; Roe, J. A.; Feigon, J. Proc. Natl. Acad. Sci. 1993, 90, 3745.

29. Schultze, P.; Macaya, R. F.; Feigon, J. J. Mol. Biol. 1994, 235, 1532.

30. Weiner, S. J.; Kollman, P. A.; Case, D. A.; Singh, U. C.; Ghio, C.; Alagona, G.; Profeta, S. Jr.; Weiner, P. J. Am. Chem. Soc. 1984, 106, 756. 
Table 1. Mass spectra and UV melting temperatures ${ }^{\mathrm{a}}$ for OCT1, OCT2 and TBA derivatives carrying acridine and quindoline molecules.

\begin{tabular}{|c|c|c|c|c|c|}
\hline Oligomers & M (Found) & $\mathrm{M}$ (Expected) & $\operatorname{Tm}\left({ }^{\circ} \mathrm{C}\right)$ & $\Delta \operatorname{Tm}\left({ }^{\circ} \mathrm{C}\right)$ & $\begin{array}{c}\Delta \mathrm{Tm} / \text { modification } \\
\left({ }^{\circ} \mathrm{C}\right)\end{array}$ \\
\hline OCT1 & 2406.2 & 2408.5 & 35.0 & -- & -- \\
\hline OCT1-p-Qut & 2819.2 & 2819.6 & 44.2 & +9.2 & +4.6 \\
\hline OCT1-p-Qut-p-Qut & 3229.3 & 3230.7 & 48.0 & +13.0 & +6.5 \\
\hline OCT1-p-Act & 2779.4 & 2780.5 & 47.0 & +12.0 & +6.0 \\
\hline OCT1-p-Act-p-Act & 3150.6 & 3152.6 & 48.0 & +13.0 & +6.5 \\
\hline OCT1-p-Act-p-Qut & 3191.3 & 3191.6 & 43.9 & +8.9 & +4.4 \\
\hline OCT1-(EG) $)_{4}-\mathrm{p}-\mathrm{Qut}$ & 3073.3 & 3075.6 & 49.7 & +14.7 & +7.3 \\
\hline TTCC-Act-p-GGAA & 2783.3 & 2780.5 & 32.0 & -3.0 & -1.5 \\
\hline OCT2 & 2408.2 & 2408.5 & 36.0 & -- & -- \\
\hline OCT2-p-Qut & 2817.8 & 2819.6 & 37.1 & +1.1 & +0.5 \\
\hline OCT2-p-Qut-p-Qut & 3228.0 & 3230.7 & 39.2 & +3.2 & +1.6 \\
\hline OCT2-p-Act-p-Qut & 3190.5 & 3191.6 & 42.1 & +6.1 & +3.0 \\
\hline OCT2-p-Act & 2779.9 & 2780.5 & 40.0 & +4.0 & +2.0 \\
\hline OCT2-(EG) $)_{4}$-p-Qut & 3073.3 & 3075.6 & 47.7 & +11.7 & +5.8 \\
\hline TBA & 4723.2 & 4723.8 & 46.0 & -- & - \\
\hline TBA-p-Act & 5098.4 & 5095.9 & 49.7 & +3.7 & +3.7 \\
\hline TBA-p-Qut & 5134.8 & 5234.9 & 50.7 & +4.7 & +4.7 \\
\hline TBA-p-Qut-p-Act & 5505.7 & 5507.0 & 53.5 & +7.5 & +7.5 \\
\hline TBA-p-Act-p-Qut & 5506.3 & 5507.0 & 49.5 & +3.5 & +3.5 \\
\hline TBA-p-Act-p-Act & 5466.8 & 5468.0 & 52.1 & +6.1 & +6.1 \\
\hline TBA-(EG) $)_{4}-\mathrm{p}-\mathrm{Qut}$ & $\begin{array}{c}5414.6 \\
\left(\mathrm{M}+\mathrm{Na}^{+}\right)\end{array}$ & 5390.9 & 52.4 & +6.4 & +6.4 \\
\hline
\end{tabular}

${ }^{a}$ Uncertainty $\pm 0.8^{\circ} \mathrm{C}$; OCT1: 5'-TTCCGGAA-3'; OCT2: 5'-CCAATTGG-3'; TBA: 5'GGTTGGTGTGGTTGG-3'. Buffer conditions for TBA derivatives: $10 \mathrm{mM}$ sodium cacodylate buffer, $100 \mathrm{mM} \mathrm{NaCl}$ and $10 \mathrm{mM} \mathrm{KCl} \mathrm{(pH} \mathrm{7.0).} \mathrm{Buffer} \mathrm{conditions} \mathrm{for} \mathrm{octamers} \mathrm{100mM} \mathrm{sodium}$ phosphate buffer and $1 \mathrm{M} \mathrm{NaCl}(\mathrm{pH} 7.0)$.

Table 2. UV melting temperatures for duplexes carrying the acridine derivative in the middle of the sequence ${ }^{\mathrm{a}}$.

\begin{tabular}{|c|c|c|c|}
\hline & $\mathrm{Y}=\mathrm{Act}$ & $\mathrm{Y}=\mathrm{C}$ & $\mathrm{Y}=\mathrm{T}$ \\
\hline $\mathrm{X}=\mathrm{C}$ & 51.3 & 37.1 & 40.7 \\
\hline $\mathrm{X}=\mathrm{T}$ & 53.9 & 39.3 & 40.9 \\
\hline $\mathrm{X}=\mathrm{G}$ & 52.6 & 54.7 & 46.2 \\
\hline $\mathrm{X}=\mathrm{A}$ & 52.5 & 42.2 & 53.3 \\
\hline
\end{tabular}

${ }^{\mathrm{a}}$ Uncertainty $\pm 0.5^{\circ} \mathrm{C}$. Buffer conditions $10 \mathrm{mM}$ sodium phosphate buffer and $50 \mathrm{mM} \mathrm{NaCl}(\mathrm{pH} 7.0)$. Sequences 5'-d(TAGAGGXTCCATTGC-3') and 5'-d(GCAATGGAYCCTCTA-3') 
Table 3. Proton chemical shift (ppm) of TBA-(EG) $)_{4}$-p-Qut in $10 \mathrm{mM}$ potassium phosphate buffer and $5 \mathrm{mM} \mathrm{KCl}(\mathrm{pH} 6.9), \mathrm{T}=5^{\circ} \mathrm{C}$

\begin{tabular}{llllllllll}
\hline & H8/H6 & H1' $^{\prime}$ & H2' & H2' & H3' & H4' & H5'/H5' & Me & NH \\
\hline G1 & 7.42 & 6.08 & 3.00 & 3.04 & 4.91 & & & -- & 12.10 \\
G2 & 8.14 & 6.01 & 3.03 & 2.35 & 5.15 & 4.44 & 4.30 & - & \\
T3 & 7.88 & 6.20 & 2.25 & 2.60 & 4.91 & 4.23 & & 1.98 & \\
T4 & 7.13 & 6.04 & 2.04 & 2.68 & 4.91 & 4.23 & 3.91 & 1.02 & 11.34 \\
G5 & 7.46 & 6.05 & 3.36 & 2.91 & 4.91 & 4.49 & 4.29 & -- & 12.20 \\
G6 & 7.80 & 6.00 & 2.81 & 2.63 & 5.15 & 4.47 & 4.27 & -- & 12.16 \\
T7 & 7.80 & 6.43 & 2.55 & 2.61 & & & & 1.97 & \\
G8 & 7.50 & 5.84 & 1.99 & 2.34 & 4.89 & & & -- & 11.24 \\
T9 & 7.07 & 5.89 & 2.04 & 2.45 & 4.71 & 3.72 & $3.05,3.55$ & 1.78 & \\
G10 & 7.42 & 6.06 & 3.67 & 2.90 & & & & -- & 11.91 \\
G11 & 8.22 & 6.04 & 2.99 & 2.34 & 5.15 & 4.42 & $4.31,4.27$ & -- & 12.33 \\
T12 & 7.91 & 6.19 & 2.25 & 2.61 & 4.94 & 4.31 & & 2.00 & 11.32 \\
T13 & 7.23 & 6.09 & 2.07 & 2.73 & 4.95 & 4.27 & 3.96 & 0.99 & \\
G14 & 7.38 & 6.05 & 2.89 & 2.97 & 5.15 & & $4.27,4.49$ & -- & 12.11 \\
G15 & 8.01 & 6.03 & 2.77 & & 4.92 & & & -- & 12.32 \\
\hline
\end{tabular}

\begin{tabular}{|c|c|c|c|c|c|c|c|c|c|c|c|c|c|c|}
\hline & H1 & $\mathrm{H} 2$ & $\mathrm{H}^{\mathrm{a}}$ & $\mathrm{H} 4$ & H6 & H7 & H8 & H9 & $\mathrm{NH}_{\text {ind }}$ & $\mathrm{H} \alpha$ & $\mathrm{H} \beta$ & $\mathrm{Me}^{\mathrm{b}}$ & NH & $\mathrm{CH}_{2} \mathrm{O}$ \\
\hline Qut & 8.06 & 7.47 & 7.97 & 7.48 & 7.94 & 7.47 & 7.00 & 7.39 & 10.55 & 4.03 & 4.30 & 1.28 & 8.90 & $\begin{array}{l}3.00- \\
3.98\end{array}$ \\
\hline
\end{tabular}

${ }^{\mathrm{a}}$ The assignments of $\mathrm{H} 3$ and $\mathrm{H} 4$ could be exchanged.

${ }^{\mathrm{b}}$ Other Me signal at $1.43 \mathrm{ppm}$

Table 4. Intramolecular NOE interactions of TBA-(EG) $)_{4}-\mathrm{p}-\mathrm{Qut} \mathrm{a}^{\mathrm{a}}$

\begin{tabular}{|c|c|}
\hline Quindoline & TBA moiety \\
\hline \multicolumn{2}{|c|}{ I mode of binding } \\
\hline $\mathrm{NH}_{\text {ind }}$ & H5"T9 \\
\hline $\mathrm{Me}$ & H6T9,H8G8, H2’T7 \\
\hline $\mathrm{H} 2$ & Н2’Т9,Н5'Т9 \\
\hline H3 & $\mathrm{H} 2$ 'T9 \\
\hline $\mathrm{H} 8$ & H2'-H2'”T9 \\
\hline H9 & H4', H5'T9 \\
\hline
\end{tabular}

\begin{tabular}{ll}
\hline & II mode of binding \\
\hline $\mathrm{NH}_{\text {ind }}$ & $\mathrm{H}$ ''G6 \\
$\mathrm{Me}$ & $\mathrm{H} 1$ 'G6, H2'G6H5'-H5'G6 \\
$\mathrm{H} 8$ & $\mathrm{H}$ 2'G6 \\
\hline
\end{tabular}

${ }^{\mathrm{a}} 10 \mathrm{mM}$ potassium phosphate buffer and $5 \mathrm{mM} \mathrm{KCl}(\mathrm{pH} 6.9), \mathrm{T}=5^{\circ} \mathrm{C}$ 
Table 5. Proton chemical shift (ppm) of OCT1-(EG) $)_{4}-\mathrm{p}-\mathrm{Qut}$ in $\mathrm{D}_{2} \mathrm{O}, 10 \mathrm{mM}$ potassium phosphate buffer and $100 \mathrm{mM} \mathrm{NaCl}(\mathrm{pH} 6.7), \mathrm{T}=10^{\circ} \mathrm{C}$

\begin{tabular}{llllllll}
\hline & H8/H6 & H5/H2A & H1' & H2' & H2' & H3' & Me \\
\hline T1 & 7.33 & -- & 5.87 & 2.34 & 2.18 & & 1.41 \\
T2 & 7.33 & -- & 5.84 & 2.44 & 2.04 & & 1.36 \\
C3 & 7.32 & 5.38 & 5.64 & 2.17 & 1.92 & 4.62 & -- \\
C4 & 7.14 & 5.32 & 5.20 & 2.03 & 1.68 & 4.60 & -- \\
G5 & 7.55 & -- & 5.21 & 2.43 & 2.38 & 4.56 & -- \\
G6 & 7.48 & -- & 5.18 & 2.42 & 2.03 & & -- \\
A7 & 7.72 & 7.60 & 5.65 & 2.54 & 2.30 & 4.78 & -- \\
A8 & 7.66 & 7.60 & 5.74 & 2.48 & 2.48 & 4.82 & --
\end{tabular}

\begin{tabular}{cccccccccccc}
\hline & Har1 & Har1 & Har1 & Har1 & Har2 & Har2 & Har2 & $\mathrm{H \alpha}$ & $\mathrm{H} \beta$ & $\mathrm{Me}$ & $\mathrm{CH}_{2} \mathrm{O}$ \\
\hline Qut $^{\mathrm{a}}$ & 6.86 & 7.07 & 7.19 & 7.76 & 6.97 & 7.50 & 7.58 & 4.00 & 3.90 & 1.18 & $3.00-3.98$ \\
\hline \multicolumn{1}{c}{ a }
\end{tabular}

Table 6. Proton chemical shift (ppm) of OCT2-(EG) $)_{4}-\mathrm{p}-\mathrm{Qut}$ in $\mathrm{D}_{2} \mathrm{O}, 10 \mathrm{mM}$ potassium phosphate buffer and $100 \mathrm{mM} \mathrm{NaCl}(\mathrm{pH} 6.7), \mathrm{T}=10^{\circ} \mathrm{C}$

\begin{tabular}{|c|c|c|c|c|c|c|c|c|c|c|}
\hline & & 3/H6 & $\mathrm{H} 5 / \mathrm{H} 2 \mathrm{~A}$ & $\begin{array}{ll}\mathrm{A} \\
\mathrm{H} 1\end{array}$ & & $\mathrm{H} 2^{\prime}$ & $\mathrm{H} 2^{\prime}$, & $\mathrm{H}$ & & $\mathrm{Me}$ \\
\hline $\mathrm{C} 1$ & 7. & & 5.72 & 5.7 & & 2.27 & 1.85 & & & - \\
\hline $\mathrm{C} 2$ & 7. & & 5.47 & 5.0 & & 2.15 & 1.88 & 4. & 65 & -- \\
\hline A3 & 8 . & & 7.09 & 5.7 & & 2.76 & 2.64 & 4. & 88 & -- \\
\hline A4(I) & 8. & & 7.65 & 5.9 & & 2.71 & 2.40 & 4. & 86 & -- \\
\hline A4(II) & 7. & & 7.65 & 5.9 & & 2.60 & 2.38 & 4. & 86 & -- \\
\hline T5 & 6. & & -- & 5.6 & & 2.24 & 1.69 & 4. & 60 & $1.08 / 1.06$ \\
\hline T6 & 6. & & -- & 5.4 & & 2.69 & 2.40 & 4. & 60 & 1.32 \\
\hline G7 & 7. & & -- & 5.2 & & 2.48 & 2.50 & 4. & 81 & -- \\
\hline \multirow[t]{2}{*}{ G8 } & 7. & & -- & 5.5 & & 2.50 & 2.50 & & & -- \\
\hline & Har1 & Har1 & Har1 & Har1 & Har2 & Har2 & Har2 & $\mathrm{H} \alpha$ & $\mathrm{H} \beta$ & $\mathrm{CH}_{2} \mathrm{O}$ \\
\hline $\mathrm{Qut}^{\mathrm{a}}$ & 7.78 & 7.82 & 7.61 & 7.25 & 7.10 & 7.15 & 6.87 & 4.00 & 4.45 & $1.20 \quad 3.00-3.98$ \\
\hline
\end{tabular}




\section{FIGURE LEGENDS}

Figure 1. A) Structure of the threoninol derivatives of acridine and quindoline (Act and Qut). B) duplex structure of a self-complementary octamer carrying an acridine derivative at the 3'-end (OCT1-p-Act).

Figure 2. ${ }^{1} \mathrm{H}-\mathrm{NMR}$ spectra of the imino resonances at $5^{\circ} \mathrm{C}$ of (a) thrombin-binding aptamer TBA; (b) TBA-p-Act; (c) TBA-p-Qut and (d) TBA-(EG) 4 -p-Qut.

Figure 3. Imino protons region of TBA-(EG) 4 -p-Qut from $5^{\circ} \mathrm{C}$ to $65^{\circ} \mathrm{C}$.

Figure 4. Region of NOESY spectrum of TBA-(EG) $)_{4}$-p-Qut in $\mathrm{H}_{2} \mathrm{O}_{2} \mathrm{D}_{2} \mathrm{O}(9: 1), 10 \mathrm{mM}$ potassium phosphate buffer and $5 \mathrm{mM} \mathrm{KCl}(\mathrm{pH}$ 6.9), showing the intramolecular crosspeaks of quindoline moiety: A) NHind/H9, B) NH/H1, C) NH/H2, D) NHind/H $\alpha$, E) NHind/H 3 .

Figure 5. Two regions of the NOESY spectra of A) TBA-(EG) 4 -p-Qut, B) TBA-p-Qut, C) TBA-pAct, showing intraresidual H1', H6/H8 and Methyl, H6/H8 interactions. Extra quindoline methyl NOEs crosspeaks was observed with: a) H6T9, b) H8G8.

Figure 6. Molecular modelling of the TBA-(EG)4-Q. The yellow represents the G quartet tetrads, the red represents the loops of the TBA and the blue corresponds to the tetraethylene glycol quindoline moiety. 

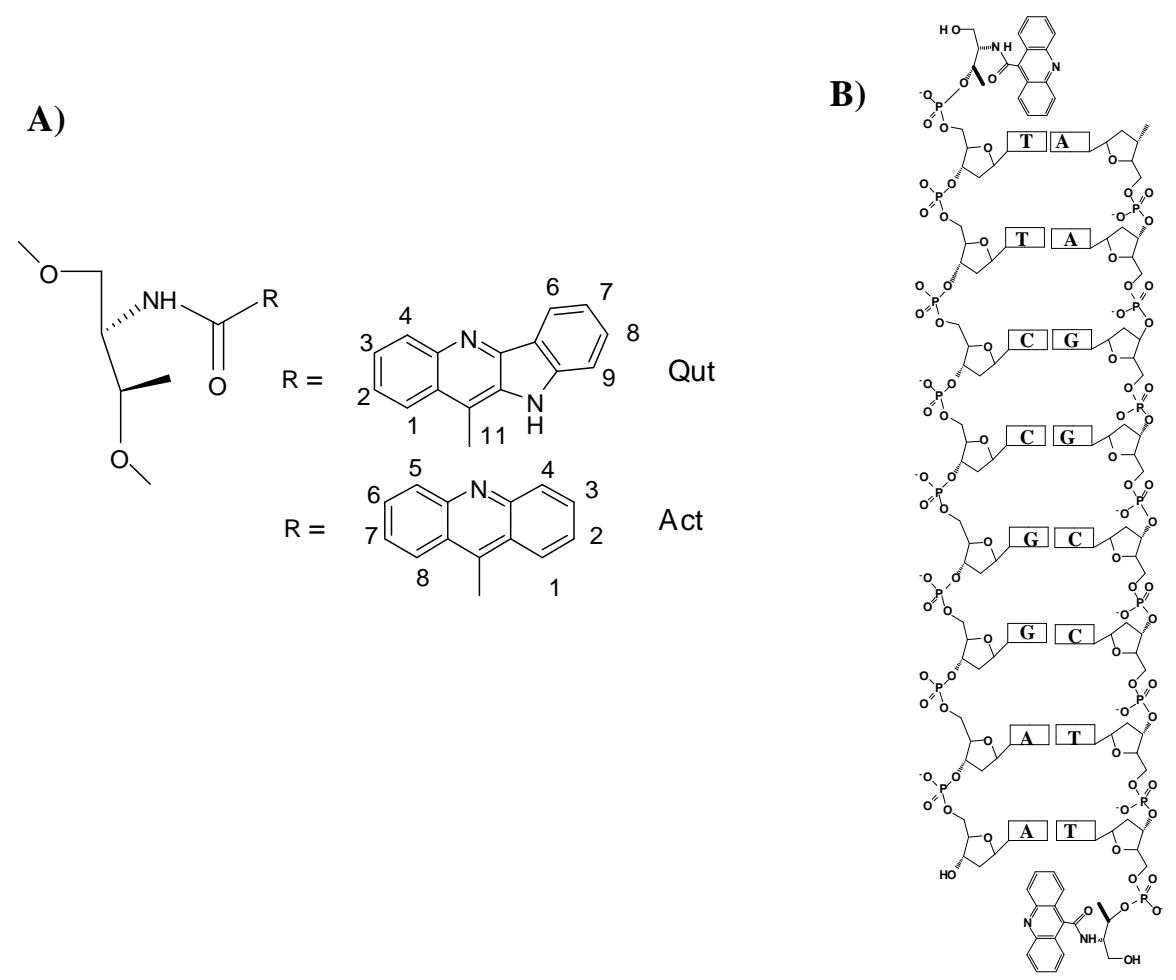

Figure 1 


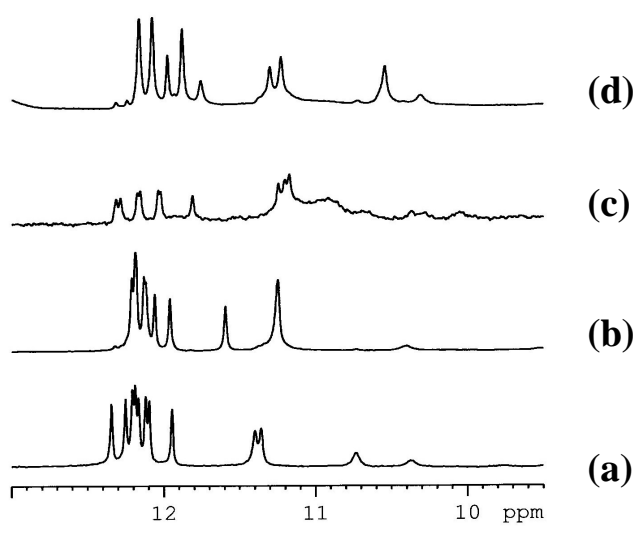

Figure 2 


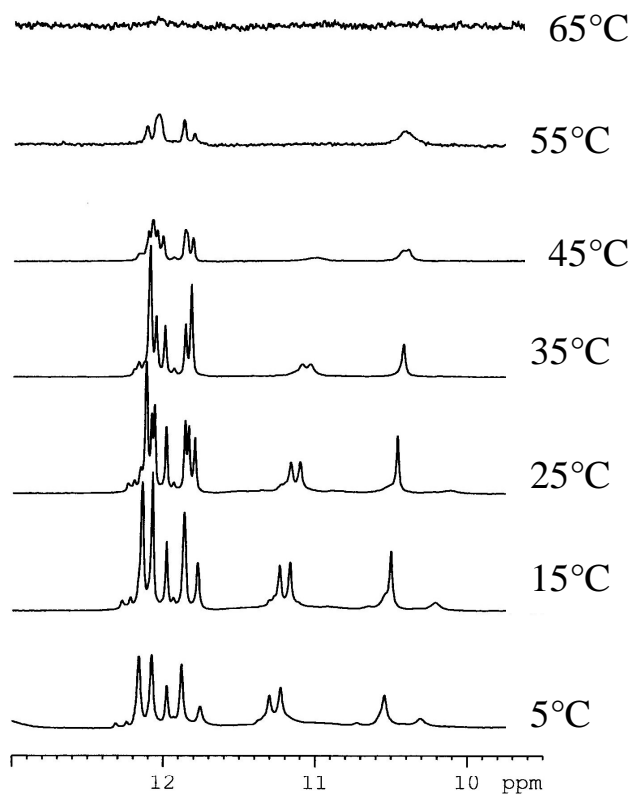

Figure 3 

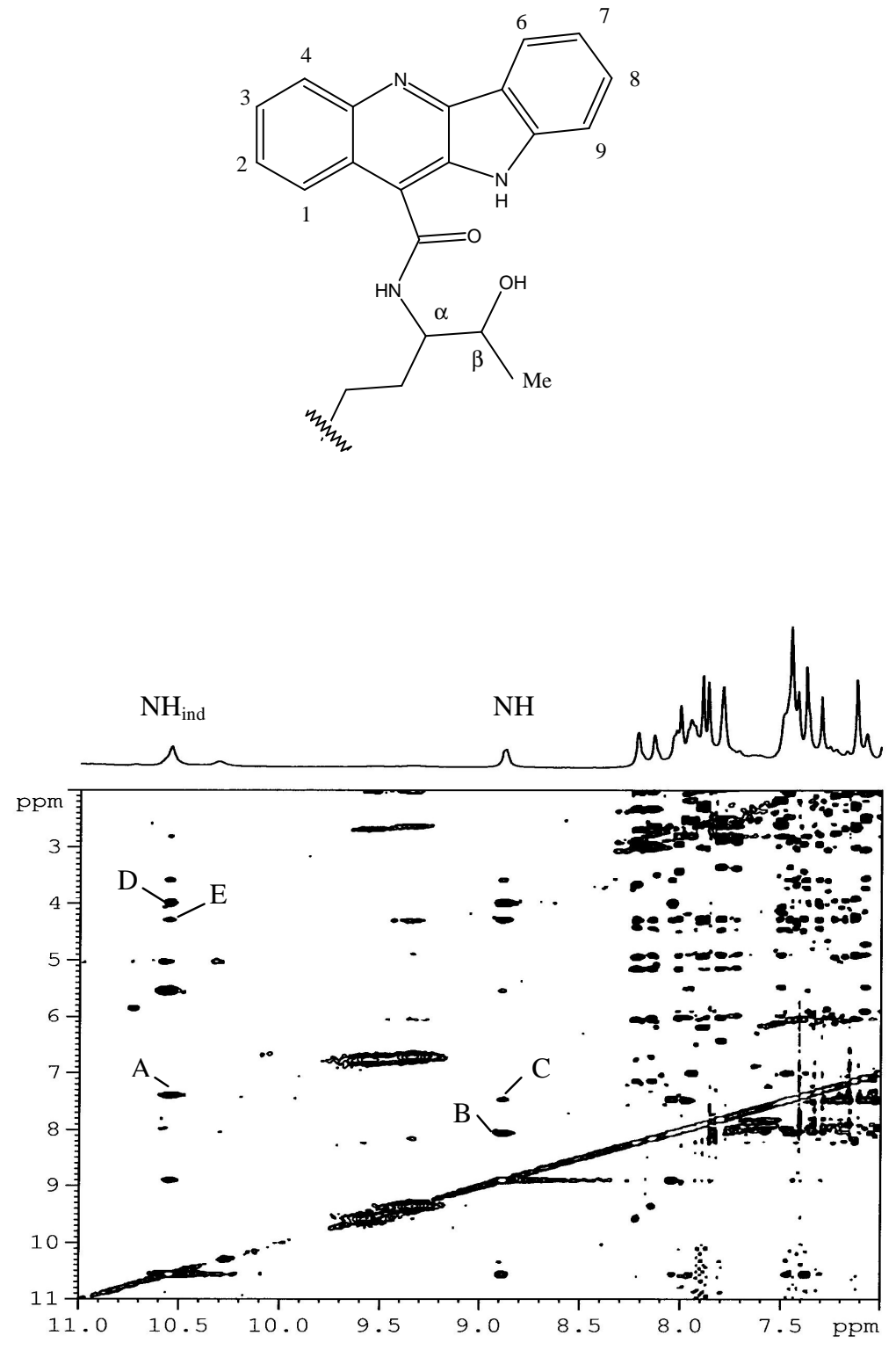

Figure 4 

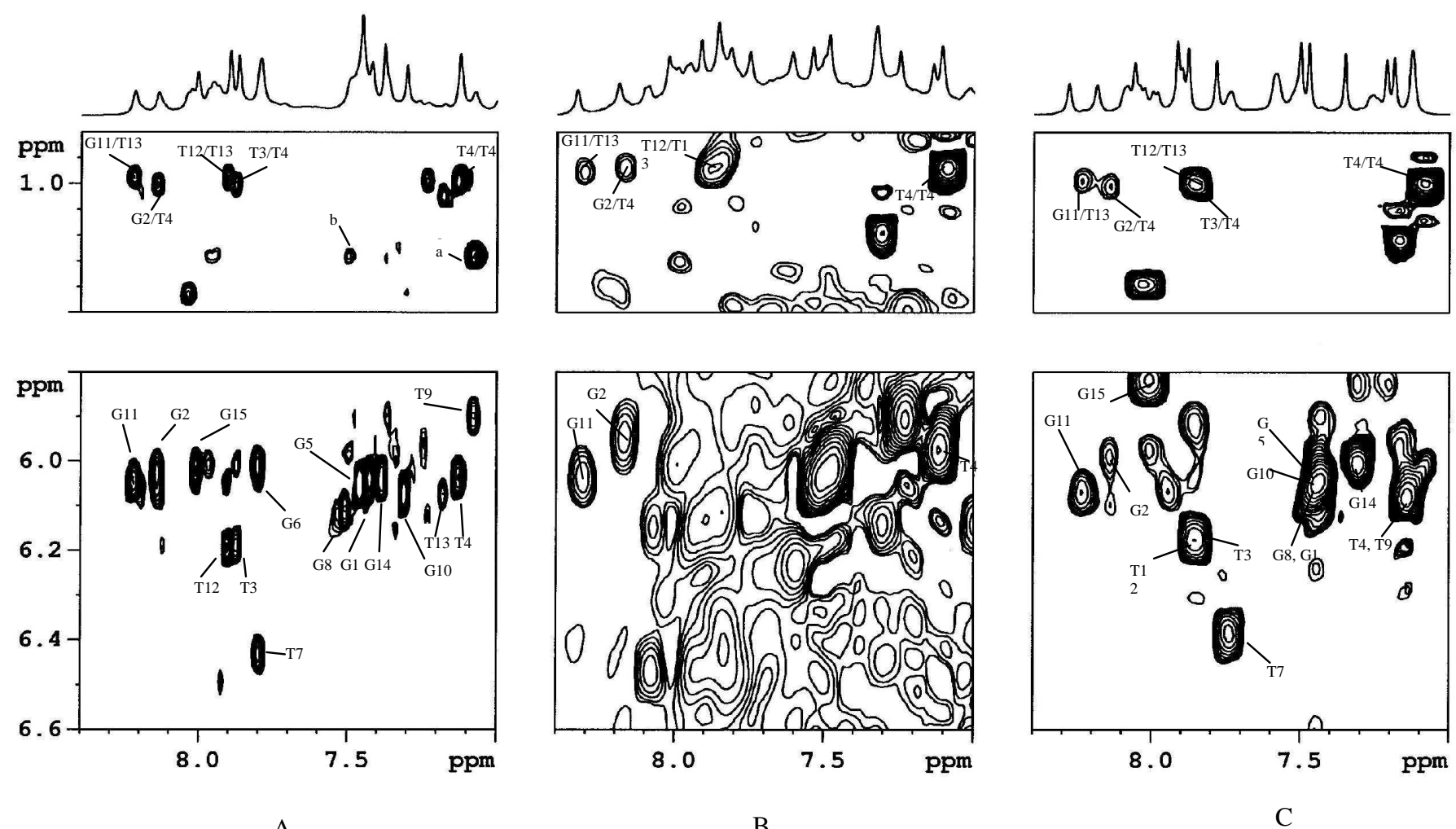

A

B

Figure 5 


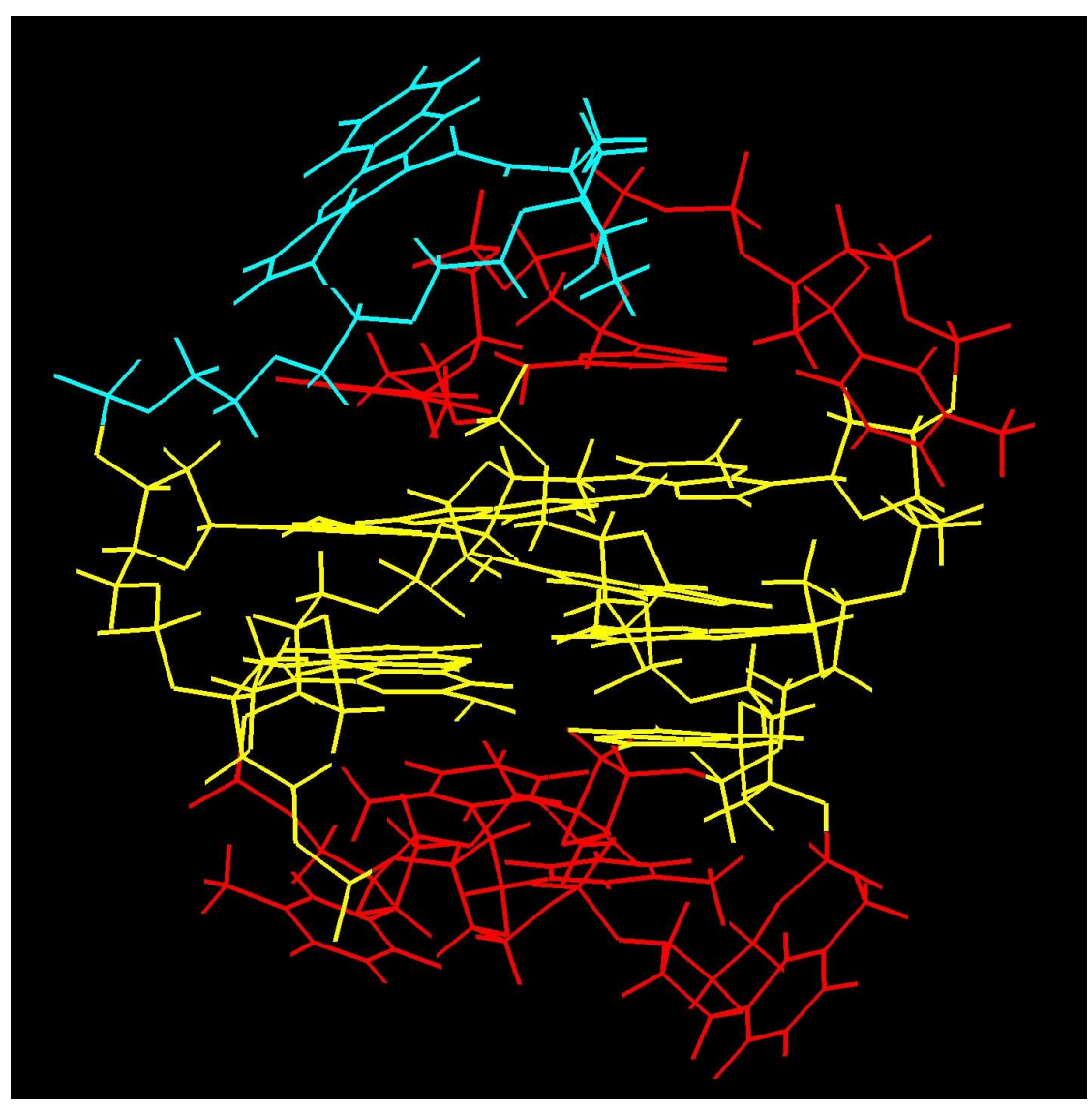

Figure 6 


\title{
SUPPLEMENTARY DATA
}

\section{Synthesis and structural properties of oligonucleotides covalently linked to acridine and quindoline derivatives through a threoninol linker}

\author{
Anna Aviñó, ${ }^{a}$ Stefania Mazzini ${ }^{\mathrm{b}, *}$ Rubén Ferreira, ${ }^{\mathrm{a}}$ and Ramon Eritja, ${ }^{\mathrm{a}, *}$ \\ ${ }^{a}$ Institute for Research in Biomedicine (IRB Barcelona), Networking Centre on Bioengineering, \\ Biomaterials and Nanomedicine (CIBER-BBN) and Institute for Advanced Chemistry of Catalonia \\ (IQAC), CSIC, Baldiri Reixac 10, E-08028 Barcelona. Spain, (Email: aaagma@cid.csic.es; \\ ruben.ferreira@irbbarcelona.org, recgma@cid.csic.es). ${ }^{b}$ Dipartimento di Scienze Molecolari \\ Agroalimentari, Università degli Studi di Milano, via Celoria 2, 20133 Milano, Italy, (Email: \\ stefania.mazzini@unimi.it).
}

INDEX:

Table 1S. Proton chemical shift (ppm) of TBA-p-Act.

Table 2S. Proton chemical shift (ppm) of OCT1-p-Qut

Table 3S. Proton chemical shift (ppm) of OCT1-(EG) 4 -p-Qut.

Figure 1S. CD spectra of TBA-(EG) $)_{4}$-pQut from $5^{\circ} \mathrm{C}$ to $75^{\circ} \mathrm{C}$ 
Table 1S Proton chemical shift (ppm) of TBA-p-Act in $10 \mathrm{mM}$ potassium phosphate buffer and 5 $\mathrm{mM} \mathrm{KCl}(\mathrm{pH} 6.9), \mathrm{T}=5^{\circ} \mathrm{C}$

\begin{tabular}{llllllllll}
\hline & H8/H6 & H1 $^{\prime}$ & H2' & H2' & H3' & H4' & H5'/H5' & Me & NH \\
\hline G1 & 7.43 & 6.10 & 2.94 & 2.96 & 4.93 & & & -- & \\
G2 & 8.12 & 6.04 & 3.04 & 2.36 & 5.18 & 4.46 & 4.31 & -- & \\
T3 & 7.81 & 6.21 & 2.26 & 2.59 & 4.93 & & & 1.99 & \\
T4 & 7.06 & 6.07 & 2.05 & 2.67 & 4.93 & & & 1.04 & \\
G5 & 7.44 & 6.06 & 3.38 & 2.89 & 4.96 & & & -- & 12.13 \\
G6 & 7.83 & 6.02 & 2.88 & 2.60 & 5.16 & & & -- & \\
T7 & 7.72 & 6.43 & 2.50 & 2.60 & & & & 1.99 & \\
G8 & 7.51 & 6.10 & 2.00 & 2.36 & & & & -- & \\
T9 & 7.06 & 5.86 & 2.05 & 2.40 & 4.92 & & $3.05,3.55$ & 1.99 & \\
G10 & 7.43 & 6.10 & 3.62 & 2.94 & 4.94 & 4.96 & & -- & \\
G11 & 8.21 & 6.05 & 3.05 & 2.37 & 5.18 & 4.46 & 4.32 & -- & \\
T12 & 7.85 & 6.21 & 2.29 & 2.61 & 4.98 & & & 2.02 & 12.05 \\
T13 & 7.15 & 6.02 & 2.05 & 2.70 & 4.91 & & & 1.04 & 12.06 \\
G14 & 7.29 & 6.05 & 2.80 & 2.92 & 5.16 & & 4.26 & -- & \\
G15 & 7.99 & 6.05 & 2.71 & 2.80 & 4.91 & & & -- & \\
\hline
\end{tabular}

\begin{tabular}{lllllllllllll}
\hline & $\mathrm{H} 1$ & $\mathrm{H} 2$ & $\mathrm{H} 3$ & $\mathrm{H} 4$ & $\mathrm{H} 5$ & $\mathrm{H} 6$ & $\mathrm{H} 7$ & $\mathrm{H} 8$ & $\mathrm{H} \alpha$ & $\mathrm{H} \beta$ & $\mathrm{Me}$ & $\mathrm{NH}$ \\
\hline Act & 7.29 & 8.01 & 7.49 & 7.49 & 7.36 & 7.72 & 7.60 & 8.08 & 4.16 & 4.47 & 1.43 & 9.21 \\
\hline
\end{tabular}

Table 2S Proton chemical shift (ppm) of OCT1-p-Qut in $\mathrm{H}_{2} \mathrm{O}, 10 \mathrm{mM}$ potassium phosphate buffer and $100 \mathrm{mM} \mathrm{NaCl}(\mathrm{pH} 6.7), \mathrm{T}=25^{\circ} \mathrm{C}$

\begin{tabular}{lllllllll}
\hline & H8/H6 & H5/H2A & H1' & H2' & H2' & H3' & Me & NH \\
\hline T1 & 7.64 & -- & 6.06 & 2.64 & 2.22 & 4.81 & 1.82 & \\
T2 & 7.49 & -- & 6.06 & 2.52 & 2.22 & 4.92 & 1.62 & \\
C3 & 7.52 & 5.68 & 5.81 & 2.49 & 2.11 & & -- & \\
C4 & 7.35 & 5.58 & 5.41 & 2.21 & 1.89 & 4.78 & -- & \\
G5 & 7.80 & -- & 5.39 & 2.47 & 2.38 & 4.88 & -- & 12.98 \\
G6 & 7.61 & -- & 5.30 & 2.58 & 2.22 & & -- & 12.57 \\
A7 & 7.78 & 7.05 & 5.40 & 2.53 & 2.22 & & -- & \\
A8 & 7.75 & 7.19 & 5.72 & 2.53 & 2.22 & & -- & \\
\hline
\end{tabular}

\begin{tabular}{lllll}
\hline & Har & Har & Me & $\mathrm{NH}_{\text {ind }}$ \\
\hline Qut & 7.90 & 7.38 & 1.31 & 9.87 \\
\hline
\end{tabular}


Table 3S Proton chemical shift (ppm) of OCT1-(EG) $)_{4}$-p-Qut in $\mathrm{D}_{2} \mathrm{O}, 10 \mathrm{mM}$ potassium phosphate buffer and $100 \mathrm{mM} \mathrm{NaCl}(\mathrm{pH} 6.7), \mathrm{T}=25^{\circ} \mathrm{C}$

\begin{tabular}{|c|c|c|c|c|c|c|c|c|c|c|c|}
\hline & \multicolumn{2}{|c|}{ H8/H6 } & \multicolumn{2}{|c|}{$\mathrm{H} 5 / \mathrm{H} 2 \mathrm{~A}$} & $\mathrm{H} 1^{\prime}$ & $\mathrm{H} 2{ }^{\prime}$ & & $\mathrm{H} 2^{\prime \prime}$ & \multicolumn{2}{|l|}{$\mathrm{Me}$} & \\
\hline $\mathrm{T} 1$ & \multicolumn{2}{|c|}{7.54} & \multicolumn{2}{|c|}{--} & 6.08 & 2.58 & & 2.42 & \multicolumn{2}{|c|}{1.66} & \\
\hline $\mathrm{T} 2$ & \multicolumn{2}{|c|}{7.46} & -- & & 6.12 & 2.66 & & 2.25 & \multicolumn{2}{|c|}{1.61} & \\
\hline C3 & \multicolumn{2}{|c|}{7.56} & 5.64 & & 5.91 & 2.43 & & 2.16 & \multicolumn{2}{|l|}{-- } & \\
\hline $\mathrm{C} 4$ & \multicolumn{2}{|c|}{7.38} & 5.58 & & 5.48 & 2.27 & & 1.80 & \multicolumn{2}{|l|}{--} & \\
\hline G5 & \multicolumn{2}{|c|}{7.79} & -- & & 5.48 & 2.68 & & 2.61 & \multicolumn{2}{|l|}{--} & \\
\hline G6 & \multicolumn{2}{|c|}{7.69} & -- & & 5.44 & 2.64 & & 2.52 & \multicolumn{2}{|l|}{-- } & \\
\hline A7 & \multicolumn{2}{|c|}{7.94} & & & 5.81 & 2.74 & & 2.64 & \multicolumn{2}{|l|}{-- } & \\
\hline A8 & \multicolumn{2}{|c|}{7.98} & & & 6.03 & 2.70 & & 2.52 & \multicolumn{2}{|l|}{--} & \\
\hline & Har1 & Har1 & Har1 & Har2 & Har2 & Har2 & Har2 & $\mathrm{H} \alpha$ & $\mathrm{H} \beta$ & $\mathrm{Me}$ & $\mathrm{CH}_{2} \mathrm{O}$ \\
\hline $\mathrm{Qut}^{\mathrm{a}}$ & 7.11 & 7.43 & 8.03 & 7.32 & 7.76 & 7.85 & nd & 4.00 & 4.40 & 1.43 & $3.00-3.98$ \\
\hline
\end{tabular}

Figure 1S. CD spectra of TBA-(EG) $)_{4}$-pQut from $5^{\circ} \mathrm{C}$ to $75^{\circ} \mathrm{C}$

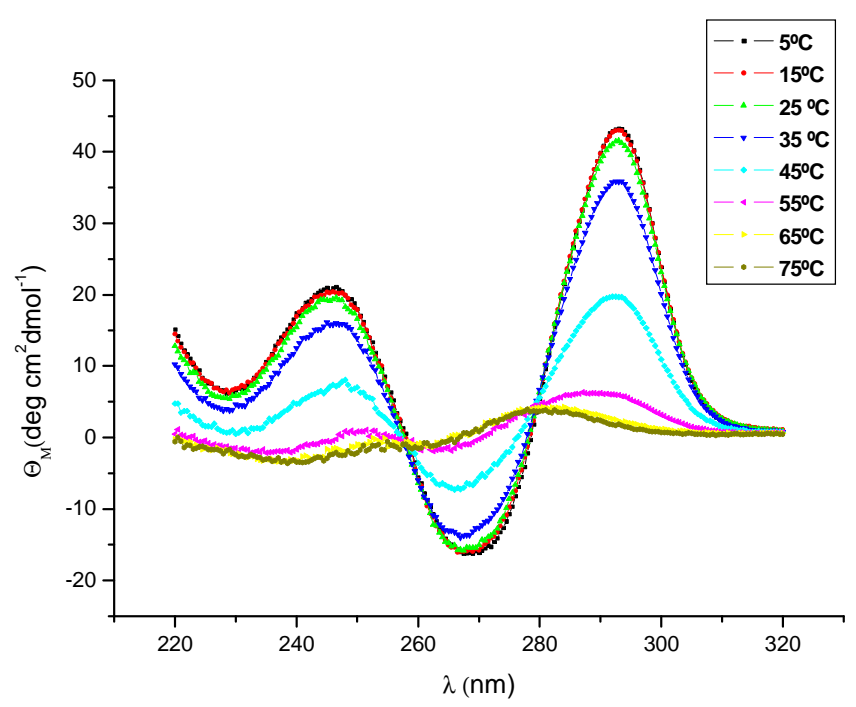

